\title{
On the Significance of Trade Relations between GCC Countries and Japan
}

\author{
Shaykha AlShamsi \\ United Arab Emirates University \\ Magda Kandil \\ International Monetary Fund
}

\begin{abstract}
Trade relations between Japan and the Gulf Cooperation Council Countries (GCC Countries) is very strong and has been growing at very high rates during the last twenty years. In 1996, Japan imported more than 65\% of its crude oil from the GCC Countries. The GCC countries' imports from Japan were $25 \%$ of their total imports in 1996. The aim of this paper is to analyze the impact of trade relations on the economies of the GCC countries and Japan.
\end{abstract}

-JEL Classifications: F10, F15, F14

- Key Words: Economic Integration, Trade Relations, Oil Production

\section{Introduction}

The Gulf Cooperation Council Countries (GCC Countries) are Bahrain, Kuwait, Oman, Qatar, Saudi Arabia, and the United Arab Emirates (UAE). Table 1 illustrates the shares of GCC countries of world oil production and reserves in 1996. The oil production of GCC countries is nearly $19 \%$ of the world oil production, which amounted to 70 million barrel per day in $1996 .{ }^{1}$ The oil reserves

\footnotetext{
*Corresponding address: Shaykha AlShamsi, Department of Economics Faculty of Economics and Administration, United Arab Emirates University.

Magda Kandil, International Monetary Fund Fund, IS4-816, 1875 Eye St., Washington D.C., 20431, Phone: (202) 623-4596 Fax: (202) 589-4696, E-mail: mkandil@inf.org.

${ }^{1}$ See Oil Market Report, International Energy Agency, April 10, 1998, Table 4, p. 483.

(c)2001-Center for International Economics, Sejong Institution, All Rights Reserved.
} 
Table 1. GCC Countries Oil Production and Reserves In 1996

\begin{tabular}{|lcccc|}
\hline & $\begin{array}{c}\text { Oil production } \\
\text { (1000 barrel per day) }\end{array}$ & $\begin{array}{c}\text { \% of the world } \\
\text { production }\end{array}$ & $\begin{array}{c}\text { Oil Reserves } \\
\text { (Billion b/year end })\end{array}$ & $\begin{array}{c}\text { Oil reserves \% } \\
\text { of the world } \\
\text { reserves }\end{array}$ \\
\hline Bahrain & 40 & 0.056 & 0.2 & \\
Oman & 900 & 1.28 & 5.0 & .45 \\
Qatar & 470 & 0.67 & 4.9 & .44 \\
Kuwait & 2000 & 2.8 & 97.7 & 8.79 \\
Saudi Arabia & 8000 & 11.39 & 262.5 & 23.6 \\
United Arab & 2190 & 3.11 & 98.1 & 8.8 \\
Emirates & 13600 & 19.4 & 468.4 & 42 \\
GCC Coun- & 70202 & 100 & 1111.3 & 100 \\
tries & & & & \\
The World & & & & \\
\hline
\end{tabular}

Sources: 1. International Energy Agency “Oil marker Report” 10 April 1998, Table 4. Page 483.

2. Opec bulletin, March 1998 page 27.

3. World Alamank Books "The World Almanac and book of facts 1997. An imprint of k-111 references corporation. A K-111 communications company.

Table 2. GCC Countries Directions of Trade in 1996

In million US dallar

\begin{tabular}{|llllll|}
\hline \multicolumn{1}{|c}{ Exports to } & \multicolumn{5}{c|}{} \\
\hline & Japan & USA & EU & Rest of the World & Total \\
\hline GCC Countries \% & 27547 & 11361.2 & 13059.3 & 49288 & 101165.5 \\
& 27.1 & 11.2 & 12.9 & 48.7 & 100 \\
UAE & 10460 & 489 & 1045 & 11666 & 23660 \\
Bahrain & 392 & 113 & 113.9 & 1940.9 & 2559.8 \\
Saudi Arabia & 9702 & 8584 & 10234 & 26853.8 & 55373.8 \\
Oman & 1773.6 & 406.8 & 192.4 & 3537.5 & 5910.3 \\
Qatar & 2246 & 148 & 36.0 & 37189 & 39619 \\
Kuwait & 2884 & 1620 & 1438 & 3757 & 9699 \\
\hline & & & & & \\
\hline Import form & & & & & \\
\hline & Japan & USA & EU & Rest of the World & Total \\
\hline GCC Countries \% & 7952 & 13714 & 29135.4 & 32927 & 83728.4 \\
& 9.5 & 16.4 & 34.8 & 39.3 & 100 \\
UAE & 2539 & 2779 & 9162 & 12997.2 & 3575.8 \\
Bahrain & 1548 & 268.1 & 877.6 & 882.1 & 27477.2 \\
Saudi Arabia & 3311 & 8025 & 13555 & 8420.7 & 33311.7 \\
Oman & 721 & 236.8 & 1587.7 & 1733.5 & 4279 \\
Qatar & 282.7 & 227.9 & 1508 & 576.9 & 2595.5 \\
Kuwait & 944 & 2177 & 2445 & 1923.7 & 7489.7 \\
\hline
\end{tabular}

Source: The Secretariat General Cooperation Council for the Arab states of Gulf "Economic Bulletin" vol. 12, 1997 (Tables 3/14-3/25). 
of the GCC Countries were $42 \%$ of the world oil reserves in 1996. The natural gas reserves of GCC were nearly $13.3 \%$ of total reserves in $1996 .^{2}$

Table 2 illustrates the directions of trade for GCC countries in 1996. The GCC Countries imported 60\% from industrial countries, especially Japan (9.5\%) and the United States (16\%). Japan's exports to GCC countries were $1.31 \%$ of its total exports in $1996 .{ }^{3}$ Exports of petroleum (crude oil and petroleum products) and liquefied gas amounted to $99 \%$ of total exports for $G C C$ countries. These products require high technology in manufacturing. ${ }^{4}$ In 1996, the shares of industrial countries of oil exports from GCC countries were as follows: $60 \%$ for Saudi Arabia, $80 \%$ for Kuwait, $51 \%$ for UAE and $73 \%$ for Qatar (see Table 2). In 1996, the shares of Japan of oil exports from GCC countries were as follows: $42 \%$ for UAE, 70\% for Kuwait, 33\% for Qatar, 20\% for Saudi Arabia and 70\% for Oman. ${ }^{5}$ In 1996, Japan imported $6.7 \%$ of its total imports from the GCC countries; these imports were mainly oil and liquefied gas. The aim of this paper is to analyze the impact of trade relations on the economies of the GCC countries and Japan. The analysis is divided into four sections. Section II will provide evidence for the growth in trade between the GCC countries and Japan between 1975-1995. Section III develops and tests a simultaneous-equation model to analyze the effects of trade on the economies of Japan and the GCC Countries, collectively and individually. Section IV summarizes major findings. All variables in the paper are measured in real terms. The data under investigation are from International Financial Statistics issued by the International Monetary Fund and from Japan External Trade Relation Organization (JETRO) Statistics.

\section{The Growth of Trade between GCC and Japan: 1975-95}

Trade statistics indicate that the economies of GCC are more foreign tradeoriented than that of Japan. To illustrate, Japan's exports (mainly manufactured

\footnotetext{
${ }^{2}$ See The World Almanac and Book of Facts 1997, World Almank Books, an imprint of k-111 references corporation, a K-111 communication company, p. 256.

${ }^{3}$ See JETRO, Japan External Trade Relations Organization, Statistics.

${ }^{4}$ For example, petrochemicals, which usually depend on oil and gas, pass through three stages. In the first stage, the inputs produce the basic petrochemicals which need industries with high investment and low technology. The second and third stages of processing require very complicated ways of manufacturing and high sophisticated technicians. Such technology is not available in developing countries.

${ }^{5}$ Although the United States accounted for $24 \%$ of the world's total energy consumption and consumed $27 \%$ more energy than it produced, its imports from the GCC countries were only $5.5 \%$ of their oil exports.
} 
products) were approximately $8.7 \%$ of its $G D P$ in 1995 . In contrast, the GCC countries' exports (mainly oil) were more than $37.6 \%$ of its GDP in the same year. The highest export share of GDP was in Bahrain (98.7\%) and the lowest share was in Oman (37.26\%). For other GCC countries, these shares in 1995 were as follows: $71.6 \%, 54.7 \%, 39.9 \%$ and $43 \%$ for UAE, Kuwait, Saudi Arabia, and Qatar, respectively. Similarly, Japan spent $6.5 \%$ of its GDP on imports in 1995.

The share of imports of GDP is the highest in Bahrain (77.7\% in 1995). ${ }^{6}$ Also the ratio of imports to $G D P$ was $67.5 \%$ in the United Arab Emirates. ${ }^{7}$ In 1995, the shares of imports of GDP were $32.9 \%$ in Kuwait, $27.7 \%$ in Oman, $30.03 \%$ in Saudi Arabia, and $26.3 \%$ in Qatar.

To illustrate other differences between Japan and GCC countries concerning the significance of trade, we estimate the marginal propensity to import for these countries using time-series data from $1975-1995 .{ }^{8}$ The marginal propensity to import is 0.05 for Japan. The marginal propensity to import is 0.29 for GCC countries, 0.97 for Bahrain, 0.64 for UAE, 0.266 for Oman, 0.278 for Saudi Arabia, 0.20 for Qatar and 0.03 for Kuwait. ${ }^{9}$ In another direction, we measure the elasticity of imports with respect to GDP using time-series data between 1975-95 for the sample of countries under investigation. ${ }^{10}$ The elasticity of imports with respect to GDP is 0.659 for Japan and 1.2989 for GCC countries. The corresponding elasticity figures for members of GCC are as follows: 1.14 for Saudi Arabia, 1.1657 for Bahrain, 0.9485 for Qatar, 0.928 for Oman and 0.2 for Kuwait.

Given the sharp differences between trade figures for Japan and GCC, we draw the reader's attention to several important differences in structure and economic performance. Japan is a developed economy with a strong industrial base and a large market (roughly 7 times that of $G C C$ countries). The difference in size relates to the difference in structure. GCC countries are less industrialized

\footnotetext{
${ }^{6}$ Bahrain is dependent on refining oil imports from Saudi Arabia to generate most of its national income. ${ }^{7}$ Two factors can be used for explanation: (i) the marginal propensity to consume is high while the productive capacity is limited, and (ii) some of the Emirates (mainly Dubai) depend on reexporting imported goods to generate income. Accordingly, Dubai exports most of the imported goods from South Asia and Western Countries to Iran, Japan and Oman.

${ }^{8}$ The marginal propensity to import is the regression coefficient measuring the response of imports to domestic income (GDP).

${ }^{9}$ As indicated before, Bahrain is dependent on refining oil imports from Saudi Arabia, as evident by the considerably higher marginal propensity to import in Bahrain compared to other countries.

${ }^{10}$ Kuwait directed most of its income to investing outside the country, producing many manufacturing food stuff and decreasing imports of investment and consumer goods.
} 
Table 3. Nominal and Real Output Growth Rates

\begin{tabular}{|cccccccc||}
\hline obs & $\begin{array}{c}\text { Japan nominal } \\
\text { GDP Growth } \\
\text { Rates }\end{array}$ & $\begin{array}{c}\text { Japan Real } \\
\text { GDP Growth } \\
\text { Rates }\end{array}$ & $\begin{array}{c}\text { GCC Countries GCC Countries Bahrain nomin- } \\
\text { Nominal GDP } \\
\text { Growth Rates }\end{array}$ & $\begin{array}{c}\text { Real GDP } \\
\text { Growth Rates }\end{array}$ & $\begin{array}{c}\text { Bl GDP Grown Real } \\
\text { Rates }\end{array}$ & $\begin{array}{c}\text { GDP Growth } \\
\text { Rates }\end{array}$ \\
\hline \hline 1975 & 0.000000 & 0.000000 & 0.000000 & 0.000000 & 0.000000 & 0.000000 \\
1976 & 12.39590 & 4.265132 & 23.05018 & 7.028109 & 39.38504 & 21.23605 \\
1977 & 23.07287 & 15.68850 & .12 .36818 & 1.767320 & 29.75424 & 17.51317 \\
1978 & 40.50577 & 33.73011 & 10.76971 & 4.369778 & 15.43134 & 8.762080 \\
1979 & 4.083301 & 1.381509 & 44.55867 & 30.62524 & 10.48646 & -0.162891 \\
1980 & 4.774853 & 0.192501 & 40.22552 & 33.35447 & 12.07207 & 6.580536 \\
1981 & 10.16845 & 6.153197 & 28.59235 & 23.76549 & 12.58959 & 8.363413 \\
1982 & -7.227368 & -8.785699 & -35.34022 & -37.62163 & 5.130762 & 1.421413 \\
1983 & 8.987776 & 7.542634 & -8.972223 & -9.643396 & 2.451123 & 1.695723 \\
1984 & 6.312408 & 3.901436 & -3.319465 & -1.039263 & 5.632298 & 8.123626 \\
1985 & 5.706897 & 4.021877 & -8.161353 & -6.214869 & -7.441860 & -5.480127 \\
1986 & 47.69027 & 45.06946 & -16.79062 & -14.90509 & -16.41541 & -14.52138 \\
1987 & 21.17457 & 21.17457 & 6.203424 & 7.474053 & 3.637153 & 4.877079 \\
1988 & 19.83536 & 19.46126 & 1.101368 & 0.004608 & 6.636520 & 5.479714 \\
1989 & -1.846996 & -3.651648 & 11.52913 & 9.366948 & 10.98906 & 8.837347 \\
1990 & 5.030078 & 2.824447 & 16.24458 & 12.96573 & 9.620843 & 6.528825 \\
1991 & 14.28482 & 12.04394 & 3.129788 & -0.838763 & 5.875324 & 1.801121 \\
1992 & 9.093907 & 7.409059 & 8.036068 & 5.562043 & 4.514673 & 2.121288 \\
1993 & 14.65236 & 13.77380 & 3.671971 & 2.059407 & 4.847612 & 3.216761 \\
1994 & 9.530077 & 9.320651 & -1.599144 & -1.994675 & 4.566259 & 4.145946 \\
1995 & 11.40313 & 11.40313 & 5.920414 & 5.920414 & 3.983805 & 3.983805 \\
& & & & & & \\
\hline
\end{tabular}

Table 3. Continued

\begin{tabular}{|ccccccc||}
\hline obs & $\begin{array}{c}\text { Oman Nominal } \\
\text { GDP Growth } \\
\text { Rates }\end{array}$ & $\begin{array}{c}\text { Oman Real } \\
\text { GD Growth } \\
\text { Rates }\end{array}$ & $\begin{array}{c}\text { Qatar Nominal } \\
\text { GDP Growth } \\
\text { Rates }\end{array}$ & $\begin{array}{c}\text { Qatar Real } \\
\text { GDP Growth } \\
\text { Rates }\end{array}$ & $\begin{array}{c}\text { Kuwait Nomin- } \\
\text { al GDP } \\
\text { Growth Rates }\end{array}$ & $\begin{array}{c}\text { Kuwait Real } \\
\text { GDP Growth } \\
\text { Rates }\end{array}$ \\
\hline \hline 1975 & 0.000000 & 0.000000 & 0.000000 & 0.000000 & 0.000000 & 0.000000 \\
1976 & 22.10948 & 6.209893 & 32.76140 & 15.47486 & 9.209453 & -5.010448 \\
1977 & 7.065387 & -3.035207 & 9.983275 & -0.392593 & 7.749339 & -2.415779 \\
1978 & 0.010932 & -5.767388 & 12.02997 & 5.557229 & 9.645916 & 3.310916 \\
1979 & 36.22386 & 23.09379 & 42.47390 & 28.74141 & 60.20304 & 44.76171 \\
1980 & 58.71938 & 50.94213 & 35.76885 & 29.11618 & 15.49579 & 9.836499 \\
1981 & 21.69627 & 17.12827 & 10.64967 & 6.496316 & 215.8401 & 203.9847 \\
1982 & 4.942050 & 1.239359 & -12.23638 & -15.33296 & -76.17699 & -77.01754 \\
1983 & 4.829388 & 4.056452 & -14.79905 & -15.42726 & -3.315173 & -4.028057 \\
1984 & 11.19377 & 13.81626 & 5.943037 & 8.441693 & 4.010062 & 6.463130 \\
1985 & 13.32481 & 15.72668 & -10.43768 & -8.539443 & -1.168292 & 0.926407 \\
1986 & -18.91819 & -17.08087 & -17.88013 & -16.01928 & -16.54151 & -14.65033 \\
1987 & 7.220559 & 8.503357 & 7.785474 & 9.075031 & 24.96174 & 26.45680 \\
1988 & -2.554233 & -3.611337 & 10.86589 & 9.663206 & -7.503833 & -8.507243 \\
1989 & 10.41399 & 8.273429 & 7.447584 & 5.364533 & 17.52211 & 15.24374 \\
1990 & 25.38418 & 21.84753 & 13.44811 & 10.24814 & -25.70350 & -27.79914 \\
1991 & -3.290152 & -7.011656 & -6.479267 & -10.07805 & -41.02148 & -43.29104 \\
1992 & 12.76377 & 10.18148 & 8.565410 & 6.079264 & 76.49123 & 72.44958 \\
1993 & 8.741731 & 7.050309 & -4.235190 & -5.724763 & 19.23580 & 17.38115 \\
1994 & 3.407932 & 2.992275 & 3.030070 & 2.615932 & -2.064511 & -2.458171 \\
1995 & 6.460734 & 6.460734 & 1.921082 & 1.921082 & 7.615153 & 7.615153 \\
& & & & & & \\
\hline
\end{tabular}


Table 3. Continued

\begin{tabular}{|ccccc||}
\hline obs & $\begin{array}{c}\text { Saudi Nominal } \\
\text { GDP Growth } \\
\text { Rates }\end{array}$ & $\begin{array}{c}\text { Saudi Real } \\
\text { GDP Growth } \\
\text { Rates }\end{array}$ & $\begin{array}{c}\text { Emirates Nomi } \\
\text {-nal GDP } \\
\text { Growth Rates }\end{array}$ & $\begin{array}{c}\text { Emirates Real } \\
\text { GDP Growth } \\
\text { Rates }\end{array}$ \\
\hline 1975 & 0.000000 & 0.000000 & 0.000000 & 0.000000 \\
1976 & 24.19580 & 8.024566 & 29.38227 & 12.53571 \\
1977 & 10.07185 & -0.312372 & 25.90296 & 14.02522 \\
1978 & 14.79683 & 8.164227 & -3.441271 & -9.020133 \\
1979 & 45.67829 & 31.63694 & 33.49060 & 20.62397 \\
1980 & 46.34412 & 39.17326 & 41.46528 & 34.53348 \\
1981 & -0.869394 & -4.590369 & 11.37070 & 7.190275 \\
1982 & -21.92127 & -24.67613 & -7.184431 & -10.45926 \\
1983 & -11.09609 & -11.75161 & -8.449278 & -9.124307 \\
1984 & -7.393058 & -5.208932 & -1.070244 & 1.263005 \\
1985 & -13.08409 & -11.24194 & -2.358371 & -0.288896 \\
1986 & -15.54247 & -13.62865 & -20.02068 & -18.20834 \\
1987 & 0.476898 & 1.679014 & 9.812523 & 11.12633 \\
1988 & 3.521483 & 2.398469 & -0.227072 & -1.309421 \\
1989 & 9.002318 & 6.889126 & 15.95651 & 13.70849 \\
1990 & 26.11475 & 22.55750 & 22.37488 & 18.92311 \\
1991 & 12.76820 & 8.428751 & 0.727672 & -3.148443 \\
1992 & 2.961248 & 0.603437 & 3.134399 & 0.772623 \\
1993 & 1.377232 & -0.199639 & 2.893330 & 1.292877 \\
1994 & -3.804957 & -4.191622 & 2.231237 & 1.820310 \\
1995 & 5.695481 & 5.695481 & 6.593825 & 6.593825 \\
& & & & \\
\hline
\end{tabular}

developing countries whose economies revolve around the production and exportation of one natural resource, i.e., oil (M. M. Metwally, 1988). The rise in oil prices played a vital role in the growth of the $G C C$ countries during the last 20 years. In contrast, the Japanese growth was due to the expansion in the productive capacity of its different sectors, particularly, the industrial sector. ${ }^{11}$

To provide further evidence of the difference in economic performance, consider the time-series movement in real GDP growth, real import growth, and real export growth for Japan and GCC countries. Growth rates are calculated to highlight difference in economic data over time across countries. Toward highlighting random movement in these data over time, Table 3 summarizes the data for real GDP growth. We note the following: (i) the highest growth rate of real GDP for GCC countries was in 1980. The increase is attributed to the increased oil production due to supply shortage in Iran.Following the revolution, the price of oil increased from 17 dollars per barrel in 1978 to 30 dollars in 1979. (ii) The highest growth rate of real GDP in Japan was in 1986. (iii) Most of the GCC countries faced a big decline in real GDP growth due to the decline of oil prices which

\footnotetext{
${ }^{11}$ The elasticity of imports is measured by the regression coefficient measuring the response of the log of imports to the log of domestic income (GDP).
} 
Table 4. Rates of Growth of Imports (in real terms)

\begin{tabular}{|c|c|c|c|c|}
\hline obs & $\begin{array}{c}\text { Japan } \\
\text { Imports } \\
\text { Growth Rates }\end{array}$ & $\begin{array}{l}\text { GCC Countries } \\
\text { Imports Growth } \\
\text { Rates }\end{array}$ & $\begin{array}{c}\text { Bahrain } \\
\text { Imports } \\
\text { Growth Rates }\end{array}$ & $\begin{array}{c}\text { Oman } \\
\text { Imports } \\
\text { Growth Rates }\end{array}$ \\
\hline $\begin{array}{l}1975 \\
1976 \\
1977 \\
1978 \\
1979 \\
1980 \\
1981 \\
1982 \\
1983 \\
1984 \\
1985 \\
1986 \\
1987 \\
1988 \\
1989 \\
1990 \\
1991 \\
1992 \\
1993 \\
1994 \\
1995\end{array}$ & $\begin{array}{r}0.000000 \\
4.075828 \\
3.337134 \\
6.628603 \\
33.85385 \\
23.01686 \\
-2.569864 \\
-9.502492 \\
-5.124383 \\
5.260150 \\
-5.704414 \\
-3.983866 \\
18.40803 \\
23.73110 \\
9.753188 \\
9.900395 \\
-1.409522 \\
-3.126851 \\
2.982543 \\
13.24269 \\
22.54937\end{array}$ & $\begin{array}{r}0.000000 \\
39.09859 \\
40.28318 \\
12.85691 \\
8.869554 \\
19.38924 \\
10.41419 \\
8.507806 \\
-8.339409 \\
-9.367152 \\
-17.42955 \\
-12.12191 \\
5.407551 \\
6.107476 \\
0.506158 \\
5.996079 \\
18.70505 \\
14.85999 \\
4.132012 \\
6.125223 \\
7.189276\end{array}$ & $\begin{array}{r}0.000000 \\
20.81983 \\
10.57199 \\
-5.211900 \\
9.862556 \\
33.32369 \\
13.93309 \\
-15.45628 \\
-8.210660 \\
7.920520 \\
-16.06358 \\
-15.37507 \\
14.59862 \\
-1.084813 \\
13.23663 \\
15.07102 \\
61.61083 \\
4.825127 \\
-10.62666 \\
-2.807067 \\
-4.001484\end{array}$ & $\begin{array}{r}0.000000 \\
-13.34541 \\
18.70071 \\
2.054420 \\
18.85391 \\
32.19358 \\
27.15415 \\
13.09557 \\
-7.775448 \\
12.86828 \\
17.17244 \\
-9.127149 \\
-13.50271 \\
-9.097149 \\
0.556305 \\
17.37302 \\
12.65925 \\
15.30025 \\
7.453520 \\
-5.218764 \\
8.496646\end{array}$ \\
\hline & & obs & $\begin{array}{c}\text { Saudi } \\
\text { Imports } \\
\text { Growth Rates }\end{array}$ & $\begin{array}{c}\text { Emirates } \\
\text { Imports } \\
\text { Growth Rates }\end{array}$ \\
\hline & & $\begin{array}{l}1975 \\
1976 \\
1977 \\
1978 \\
1979 \\
1980 \\
1981 \\
1982 \\
1983 \\
1984 \\
1985 \\
1986 \\
1987 \\
1988 \\
1989 \\
1990 \\
1991 \\
1992 \\
1993 \\
1994 \\
1995\end{array}$ & $\begin{array}{r}0.000000 \\
79.49146 \\
52.65166 \\
30.84003 \\
7.715194 \\
18.26634 \\
12.52462 \\
11.20175 \\
-4.331518 \\
-11.97081 \\
-28.41091 \\
-17.25900 \\
6.480736 \\
7.149102 \\
-4.779133 \\
10.63093 \\
15.79273 \\
12.10706 \\
5.489196 \\
0.144626 \\
4.936794\end{array}$ & $\begin{array}{r}0.000000 \\
8.013435 \\
37.33189 \\
-2.162139 \\
16.97480 \\
20.70647 \\
4.981229 \\
1.729592 \\
-18.49868 \\
-13.72537 \\
6.295295 \\
-2.518773 \\
14.31661 \\
6.834417 \\
9.942327 \\
16.62742 \\
15.37053 \\
23.61220 \\
10.35016 \\
21.85963 \\
10.89897\end{array}$ \\
\hline
\end{tabular}

reached 7 dollars per barrel in 1986. This decline in price resulted from the huge supply of oil from the $G C C$ countries and from new discoveries in many areas. (iv) Real GDP growth rates in GCC countries increased in 1990 due to the increase of oil prices during the second Gulf war and the shortage of the Kuwaiti supply of oil. 
Table 5. Rates of Growth of Exports (in real terms)

\begin{tabular}{|c|c|c|c|c|c|c|}
\hline year & $\begin{array}{c}\text { Japan } \\
\text { Exports } \\
\text { Growth Rates }\end{array}$ & $\begin{array}{l}\text { GCC Countries } \\
\text { Exports Grow- } \\
\text {-th Rates }\end{array}$ & $\begin{array}{l}\text { Bahrain } \\
\text { Exports } \\
\text { Growth Rates }\end{array}$ & $\begin{array}{c}\text { Oman } \\
\text { Exports } \\
\text { Growth Rates }\end{array}$ & $\begin{array}{c}\text { Qatar } \\
\text { Exports } \\
\text { Growth Rates }\end{array}$ & $\begin{array}{c}\text { Kuwait } \\
\text { Exports } \\
\text { Growth Rates }\end{array}$ \\
\hline $\begin{array}{l}1975 \\
1976 \\
1977 \\
1978 \\
1979 \\
1980 \\
1981 \\
1982 \\
1983 \\
1984 \\
1985 \\
1986 \\
1987 \\
1988 \\
1989 \\
1990 \\
1991 \\
1992 \\
1993 \\
1994 \\
1995\end{array}$ & $\begin{array}{r}0.000000 \\
12.06022 \\
13.21750 \\
15.44971 \\
1.312136 \\
21.92822 \\
11.91644 \\
-10.19168 \\
4.791916 \\
12.85103 \\
2.734189 \\
16.85052 \\
9.740602 \\
14.20054 \\
1.730227 \\
2.561294 \\
7.302815 \\
6.279323 \\
5.867225 \\
8.787604 \\
12.09587\end{array}$ & $\begin{array}{r}0.000000 \\
8.357480 \\
-1.270930 \\
-9.794160 \\
42.62473 \\
47.61989 \\
2.395381 \\
-32.67947 \\
-30.51840 \\
-7.554673 \\
-14.70816 \\
-23.28960 \\
14.76241 \\
-1.461626 \\
23.34400 \\
27.40433 \\
-5.009296 \\
8.854852 \\
-3.071653 \\
1.880935 \\
10.43742\end{array}$ & $\begin{array}{r}0.000000 \\
9.642437 \\
10.22382 \\
-16.98551 \\
38.49894 \\
37.77078 \\
15.90625 \\
-15.91515 \\
-16.16951 \\
0.397747 \\
-13.94610 \\
0.510669 \\
-7.079615 \\
0.199800 \\
10.14664 \\
37.25331 \\
32.99841 \\
3.068767 \\
13.25433 \\
4.435793 \\
7.038757\end{array}$ & $\begin{array}{r}0.000000 \\
-5.522550 \\
-8.954857 \\
-9.414339 \\
29.44106 \\
44.52777 \\
29.20251 \\
7.073626 \\
17.88664 \\
-4.817756 \\
22.38208 \\
-49.55167 \\
39.43392 \\
-18.80789 \\
51.96705 \\
31.57912 \\
-14.96808 \\
8.827538 \\
-3.867901 \\
4.243023 \\
3.001868\end{array}$ & $\begin{array}{r}0.000000 \\
5.839033 \\
-4.732351 \\
-6.024991 \\
32.78214 \\
24.65856 \\
16.16865 \\
-18.07667 \\
-21.32559 \\
30.22826 \\
-26.68102 \\
-34.04702 \\
-0.465885 \\
-1.324841 \\
20.06737 \\
22.50103 \\
-10.04926 \\
8.800134 \\
8.960996 \\
-15.21753 \\
1.857683\end{array}$ & $\begin{array}{r}0.000000 \\
-6.751133 \\
-10.28028 \\
0.723400 \\
59.88084 \\
1.357868 \\
-21.46788 \\
-34.67537 \\
5.110253 \\
3.417310 \\
-7.861414 \\
-28.00325 \\
13.27199 \\
-8.302366 \\
46.89360 \\
-40.36799 \\
-85.14438 \\
498.1145 \\
51.48044 \\
12.87000 \\
11.34446\end{array}$ \\
\hline
\end{tabular}

\begin{tabular}{|ccc||}
\hline & $\begin{array}{c}\text { Saudi } \\
\text { Exports } \\
\text { year }\end{array}$ & $\begin{array}{c}\text { Emirates } \\
\text { Exporth Rates } \\
\text { Growth Rates }\end{array}$ \\
\hline \hline 1975 & 0.000000 & 0.000000 \\
1976 & 12.19214 & 14.20367 \\
1977 & 2.812209 & -8.474717 \\
1978 & -11.84557 & -10.76455 \\
1979 & 40.95303 & 35.17574 \\
1980 & 63.54453 & 44.02927 \\
1981 & 5.769298 & -1.137510 \\
1982 & -36.36181 & -23.51946 \\
1983 & -42.43224 & -13.50110 \\
1984 & -16.20223 & -0.990206 \\
1985 & -25.25383 & 1.047321 \\
1986 & -24.88485 & -9.793558 \\
1987 & 16.30694 & 15.72190 \\
1988 & 3.937908 & -2.697902 \\
1989 & 14.17224 & 23.83287 \\
1990 & 52.08284 & 30.02902 \\
1991 & 3.468756 & -0.205254 \\
1992 & 2.785925 & 0.210296 \\
1993 & -16.99370 & 5.270535 \\
1994 & 0.112535 & 1.775900 \\
1995 & 17.42620 & 2.515976 \\
\hline
\end{tabular}

The only exception was Kuwait which experienced a decline in real GDP growth in $1990(-27.7 \%)$ and $1991(-43.29 \%)$. This is in contrast to high growth rates of $G D P$ for other $G C C$ countries which reached $18.9 \%$ in the UAE and $6.88 \%$ in 
Saudi Arabia.

Table 4 summarizes the growth rates of imports for Japan and $G C C$ countries. We note the following: (i) The imports of GCC countries accelerated in 1976 and 1977 as a result of the huge increase in oil revenues after the increase in oil price from \$2 per barrel in 1972 to $\$ 13$ per barrel in 1973. The highest increase was in Saudi Arabia which produced $60 \%$ of GCC oil. (ii) Oman alone reduced its imports because it was not affected by the increase of oil prices due to the small quantity of oil produced in the seventies. Also, the end of the war between the government and the revolution in South of Oman in 1976 reduced the imported weapons. (iii) Due to the increase of oil prices from $\$ 17$ per barrel to $\$ 30$ per barrel in 1979, as a result of the Iranian revolution, the oil revenues increased and, therefore, the GCC countries' imports in 1979. In 1980, the war between Iran and Iraq started and many of the GCC countries provided Iraq with imported weapons in order to protect themselves from the Iranian revolution. Accordingly, imports of the GCC countries increased, on average, by $19 \%$. (iv) The increase of oil supply in 1986 led to the decrease of oil prices (seven dollars per barrel). The reduction in oil revenues led to the reduction in the growth of imports for the GCC countries in mid eighties. Some political analysts pointed to the increasing shares of Kuwait, Saudi Arabia, and the UAE of oil supply as the main cause of the second Gulf war. Following the war, the price of oil barrel soared to $\$ 40$ per barrel. Subsequent increase in oil revenues increased the growth of imports for the $G C C$ countries in 1991 and 1992, 18\% and 14\% respectively. We also expect that imported weapons occupied a big part of these imports after the second Gulf war. In general, fluctuation in oil prices determined fluctuations in import growth for the $G C C$ countries. (v) Japan imports nearly $60 \%$ of its oil imports from the GCC countries with oil representing approximately $11 \%$ of its imports in the seventies and eighties (Japan year book 1997). Accordingly, the increase of oil prices increased the real value of Japan's imports by $33.8 \%$ in 1979. The decrease in the growth of real imports for Japan in the early eighties can be explained by the reduction in oil prices.

Table 5 summarizes the rate of growth of exports (measured in constant prices) for Japan and GCC countries. We note the following. (i) The growth of Japan's exports between 1976 and 1978 appears in sharp contrast to the reduction in exports for the GCC countries. The increase of Japan's exports was due to the

\footnotetext{
${ }^{12}$ Japan is an export-led economy. The development of the country's industrial base has focused on strong desire to compete internationally with Japanese exports.
} 
Table 6. Trade Figures between Japan \& GCC Countries

\begin{tabular}{|ccccc|}
\hline \multicolumn{1}{|c}{ GXJ= } & GMJ= & G1= & G2= \\
\hline \hline GCC Countries & $\begin{array}{c}\text { Exports to Japan } \\
\text { (Millions of US dollar) }\end{array}$ & $\begin{array}{c}\text { GCC Countries } \\
\text { Imports from Japan } \\
\text { (Millions of US dollar) }\end{array}$ & $\begin{array}{c}\text { GXJ/GCC } \\
\text { Countries } \\
\text { Total Exports }\end{array}$ & $\begin{array}{c}\text { GMJ/GCC } \\
\text { Countries } \\
\text { Total Imports }\end{array}$ \\
\hline \hline 1975 & 17364.60 & 2758.831 & 20.73839 & 14.21657 \\
1976 & 19238.38 & 4064.841 & 21.20410 & 15.05881 \\
1977 & 19107.39 & 5595.702 & 21.33082 & 14.77733 \\
1978 & 17678.76 & 6895.849 & 21.87879 & 16.13619 \\
1979 & 23032.93 & 7371.889 & 19.98600 & 15.84476 \\
1980 & 35038.01 & 9736.895 & 20.59545 & 17.52920 \\
1981 & 36644.63 & 11250.67 & 21.03594 & 18.34405 \\
1982 & 28579.94 & 12643.74 & 24.37055 & 18.99903 \\
1983 & 26624.75 & 12190.01 & 32.67530 & 19.98376 \\
1984 & 25426.62 & 10711.77 & 33.75498 & 19.14730 \\
1985 & 23112.14 & 8740.670 & 35.97344 & 16.38905 \\
1986 & 14098.64 & 6574.634 & 28.60650 & 16.28072 \\
1987 & 13728.92 & 6884.352 & 24.27304 & 15.37199 \\
1988 & 12329.88 & 6897.082 & 22.12285 & 14.01114 \\
1989 & 14727.10 & 6318.318 & 21.42307 & 14.11497 \\
1990 & 20662.80 & 6746.800 & 23.59225 & 13.40168 \\
1991 & 20117.57 & 7604.076 & 24.18102 & 14.38084 \\
1992 & 21896.55 & 9372.171 & 24.17837 & 13.30238 \\
1993 & 19915.12 & 9027.541 & 22.68733 & 9.591186 \\
1994 & 21191.86 & 6907.662 & 23.69609 & 8.009530 \\
1995 & 24076.23 & 6183.255 & 24.37697 & \\
\hline
\end{tabular}

\begin{tabular}{|cccc||}
\hline & GJ1= & GJ2= & XMGJ= \\
\hline \hline Year & $\begin{array}{c}\text { GXJ/Japan } \\
\text { Total } \\
\text { Imports }\end{array}$ & $\begin{array}{c}\text { GMJ/Japan } \\
\text { Total } \\
\text { Exports }\end{array}$ & $\begin{array}{c}\text { GCC Countries } \\
\text { Current Account } \\
\text { with Japan }\end{array}$ \\
\hline \hline 1975 & 19.63357 & 3.237588 & 14605.77 \\
1976 & 20.90033 & 4.256852 & 15173.54 \\
1977 & 20.08767 & 5.175902 & 13511.69 \\
1978 & 17.43036 & 5.524924 & 10782.91 \\
1979 & 16.96574 & 5.829830 & 15661.04 \\
1980 & 20.97966 & 6.315291 & 25301.12 \\
1981 & 22.52040 & 6.520147 & 25393.96 \\
1982 & 19.40843 & 8.159021 & 15936.20 \\
1983 & 19.05723 & 7.506521 & 14434.74 \\
1984 & 17.29016 & 5.845080 & 14714.85 \\
1985 & 16.66707 & 4.642574 & 14371.47 \\
1986 & 10.58893 & 2.988512 & 7524.006 \\
1987 & 8.708234 & 2.851539 & 6844.569 \\
1988 & 6.320821 & 2.501574 & 5432.793 \\
1989 & 6.878834 & 2.252680 & 8408.782 \\
1990 & 8.781881 & 2.345375 & 13916.00 \\
1991 & 8.672393 & 2.463484 & 12513.50 \\
1992 & 9.743966 & 2.856898 & 12524.38 \\
1993 & 8.605564 & 2.599337 & 10887.58 \\
1994 & 8.086402 & 1.828289 & 14284.20 \\
1995 & 7.496586 & 1.459961 & 17892.97 \\
\hline
\end{tabular}


with a minimum of $\$ 5432.793$ millions in 1988 and a maximum of $\$ 25393.96$ millions in 1981.

To draw more specific evidence, consider trade relations between each of the $G C C$ countries and Japan. Details of the trade figures for each of the GCC countries are provided in the data appendix. The value of Bahrain's exports to Japan has been fairly stable over time. Accordingly, Bahrain's exports to Japan in 1995 equals 1.2 times its value in 1975. The low value of exports is due to the low production of oil in Bahrain. Nonetheless, the value of imports from Japan to Bahrain grew over time; it doubled in 1977 compared to 1975 and reached nearly four folds in 1983. Subsequently, the value of imports decreased where its value was lower in 1995 compared to 1975. Most of these imports were manufactured consumer goods.

The evidence for Kuwait indicates the reduction in trade relations with Japan over the last two decades. Consistently, Kuwait's exports to Japan decreased nearly 30\% in 1995 compared to their level in 1982. The reduction started in 1982 and reached its highest level in 1991, i.e., during the second Gulf war. The decrease in Kuwaiti exports to Japan can be primarily explained by the reduction in oil revenues in real terms. In contrast, Japan's exports to Kuwait increased by 119\% between 1975-86. In 1990, Kuwait's imports from Japan decreased by $67 \%$ compared to 1986. Kuwait's trade contracts with the U.S. shifted the direction of imports from Japan, decreasing these imports. Consistent with the reduction in the value of exports, Kuwaiti exports to Japan represented approximately $25 \%$ of total Kuwaiti exports in the seventies. This ratio dropped starting 1981 to an average of approximately $15 \%$. Also, the ratio of Kuwaiti imports from Japan to total Kuwaiti imports dropped significantly between 1987-1995 compared to the earlier period. Consistently, Kuwaiti exports to Japan represented 4\% of Japan's total imports in 1975 and diminished to $0.79 \%$ in 1995 . Also Kuwaiti imports to Japan's total exports diminished from $0.75 \%$ to $0.13 \%$ over the same period. While Kuwaiti trade balance with Japan was mostly in surplus over time, it switched to deficit with the marked drop in oil revenue in 1982, 1984-86, and in 1991.

In contrast to the previous countries of $G C C$, trade relations between Japan and Oman were increasing over time. As evident in the Data Appendix, Omani exports to Japan increased by $90 \%$ between $1975-1995$. These exports are primarily in the form of mineral resources like copper and iron. Since Omani oil production is low compared with other $G C C$ countries, the increased exports were coupled with an increase in Omani imports from Japan by 614\% between 1975-95. Consistently, 
the ratio of Omani imports from Japan to total Japanese exports increased from $0.10 \%$ in 1975 to $0.14 \%$ in 1995 . Given the parallel increase in exports and imports, Oman has continuously run a surplus with Japan, except for the period 1987-1990.

Trade relations were also increasing between Japan and Qatar between 19751995. Evidence of this increase is as follows. In 1995, Japanese imports from Qatar were 48 times their level in 1975. Qatar's imports from Japan more than doubled over the same period. Consistently, Qatar's exports to Japan reached $67.1 \%$ of its total exports in 1995 compared to $1.3 \%$ in 1975. In contrast, Japan exported to Qatar nearly $15 \%$ of its total imports in 1975 . This ratio did not change much between 1975-95. Trade with Qatar (both exports and imports) represents, however, a share that is less than $1 \%$ of Japan's total trade, on average, over time.

There is some evidence that trade relations between Japan and Saudi Arabia were increasing slightly in real terms in the last two decades. Exports have increased by $0.9 \%$ in 1995 compared to 1975 . The sharpest increase was between 1978 and 1984 (26\%). Japan's exports to Saudi Arabia more than doubled between 1975-1995. The sharpest increase was between 1979 and 1984 (56\%). On average, 20\% of Saudi's exports were directed to Japan between 1975-1995. Saudi's imports from Japan averaged $15 \%$ of its total imports over the same period. In 1975, Saudi's exports to Japan were 11\% of Japan's total imports. These exports were primarily crude oil. This ratio decreased, however, over time. Between 1985-95, Saudi's exports to Japan amounted to only 3\%, on average, of Japan's total imports. Further, Saudi's imports from Japan amounted to less than 3\% of Japan's total exports between 1975-95.

The evidence for the United Arab Emirates also indicates an increase in trade relations with Japan over time. In 1995, Japanese exports to the UAE were three times their level in 1975. The ratio of the Emirates' exports to Japan out of total exports indicates that Japan is the main importer of the Emirates' oil exports. Indeed, the Emirates' exports to Japan were approximately $20 \%$ of its total exports in the seventies, peaked in mid-eighties to approximately $60 \%$, and remained around one-third in the nineties. The ratio of the Emirates' imports from Japan was, on average, $15 \%$ of its total imports in 1975, peaked in 1983 to $19.4 \%$ and declined to $10.36 \%$ in 1994. It is interesting to note that these imports represented $0.9 \%$ of Japan's total exports, on average, indicating the small size of the Emirates' market which is largely invaded by Japanese products. Further the Emirates has continuously run a trade surplus with Japan since 1975 due to the 
increasing oil exports from the Emirates to Japan.

\section{Time-Series Empirical Models}

Given trade figures discussed above, we expect that economic conditions in Japan would exert significant influence on the national income of the GCC countries. Towards the investigation of this hypothesis, we build a simultaneousequation model to test the interaction between Japan's economy and the economies of the GCC countries, collectively and individually.

In an open economy macro model, see, e.g., Kandil and Metwally (1990), aggregate demand combines domestic demand as well as foreign demand for goods and services, i.e., exports. The increased demand increases national income, resulting further increase in domestic demand as well as the demand for foreign goods and services, i.e., imports.

Assume, for example, an increase in autonomus demand in Japan, resulting an increase in domestic national income and, therefore, imports. This indicates an increase in the exports of Japan's trading partners, including the $G C C$ countries.

Table 7. Exports to Japan and GDP in GCC Countries

\begin{tabular}{|lccccc|}
\hline Country & $a_{1}$ & $a_{2}$ & $a_{3}$ & $a_{4}$ & $R^{2}$ \\
\hline$G C C$ & 5622.73 & $5.057^{*}$ & $0.62^{*}$ & -0.01 & 0.90 \\
& $(0.36)$ & $(7.11)$ & $(5.54)$ & $(-0.099)$ & \\
Bahrain & -589.02 & $3.40^{*}$ & $0.69^{*}$ & $0.31^{*}$ & 0.97 \\
& $(-1.39)$ & $(3.70)$ & $(5.94)$ & $(2.87)$ & \\
Kuwait & $2604.09^{*}$ & $3.14^{*}$ & $0.99^{*}$ & $0.047^{*}$ & 0.99 \\
& $(2.24)$ & $(7.94)$ & $(31.75)$ & $(1.73)$ & \\
Oman & $1486.7^{*}$ & $0.65^{*}$ & -0.25 & 0.011 & 0.95 \\
& $(2.15)$ & $(1.95)$ & $(3.79)$ & $(0.043)$ & \\
Qatar & $4094.04^{*}$ & $1.27^{*}$ & -0.25 & 0.24 & 0.60 \\
& $(2.91)$ & $(2.00)$ & $(-0.93)$ & $(0.97)$ & \\
Saudi Arabia & 10462.02 & $4.46^{*}$ & $0.63 *$ & 0.11 & 0.87 \\
& $(0.90)$ & $(5.20)$ & $(5.17)$ & $(0.72)$ & \\
UAE & $10516.1^{*}$ & $2.19^{*}$ & 0.22 & 0.12 & 0.84 \\
& $(3.72)$ & $(4.17)$ & $(1.021)$ & $(0.057)$ & \\
\hline
\end{tabular}

Notes: • Empirical Model: $G G D P_{t}=a_{1}+a_{2} G X J_{t}+a_{3} G N O G D P_{t}+a_{4} G G D P_{t-1}+e_{1 t}$

- GGDP $P_{t}: G D P$ of $G C C$ countries in period $t$.

- $G X J_{t}$ : Exports of $G C C$ countries to Japan in period $t$.

- GNOGDP: GCC Countries' non-oil GDP in period $t$.

- $\mathrm{e}_{1 t}$ is a random iid error term.

- $t$-ratios are in parantheses.

-* and $* *$ denote statistical significance at the five and ten percent levels, respectively. 
An increase in the $G C C$ countries' exports acts as an increase in any element of domestic demand, raising national income in the GCC countries. This, in turn, will raise imports in the $G C C$ countries, including imports from Japan. Subsequently, Japan's exports increase and, therefore, its national income.

Given the simultaneous interaction between national incomes in Japan and the $G C C$ countries, we build a simultaneous-equation model that incorporates the mutual interaction between relevant variables.

The structural equations of the model take the following form:

$$
\begin{gathered}
G G D P_{t}=a_{1}+a_{1} G X J_{t}+a_{3} G N O G D P_{t}+a_{4} G G D P_{t-1}+e_{1 t} \\
G M J_{t}=a_{5}+a_{6} G G D P_{t}+a_{7} G M J_{t-1}+e_{2 t} \\
J G D P_{t}=a_{8}+a_{9} G M J_{t}+a_{10} J X M G_{t}+a_{11} J G D P_{t-1}+e_{3 t} \\
G X J_{t}=a_{12}+a_{13} J G D P_{t}+a_{14} G C C O I L_{t}+a_{15} G X J_{t-1}+e_{4 t}
\end{gathered}
$$

The endogenous variables in the model are defined as follows:

- GGDP: $G D P$ of $G C C$ countries in period $t$.

- $G M J_{t}: G C C$ countries' imports from Japan in period $t$.

Table 8. GDP in GCC Countries and Imports from Japan

\begin{tabular}{|ccccc|}
\hline Gountry & $a_{5}$ & $a_{6}$ & $a_{7}$ & $R^{2}$ \\
\hline GCC & -240.59 & $0.017^{*}$ & $0.67^{*}$ & 0.90 \\
& $(-0.20)$ & $(2.61)$ & $(6.41)$ & \\
Bahrain & $226.65^{*}$ & $-0.027^{* *}$ & $0.64^{*}$ & 0.97 \\
& $(2.75)$ & $(-1.75)$ & $(3.26)$ & \\
Kuwait & 55.85 & $0.10^{*}$ & $0.80^{*}$ & 0.99 \\
& $(0.36)$ & $(2.073)$ & $(6.59)$ & \\
Oman & 32.24 & $0.024^{* *}$ & $0.52^{*}$ & 0.95 \\
& $(0.48)$ & $(1.86)$ & $(2.69)$ & \\
Qatar & $212.66^{*}$ & -0.0033 & 0.31 & 0.60 \\
& $(2.0065)$ & $(-0.23)$ & $(1.55)$ & \\
Saudi Arabia & -1095.41 & $0.022^{*}$ & $0.72^{*}$ & 0.87 \\
& $(-1.33)$ & $(2.90)$ & $(7.02)$ & \\
UAE & -146.81 & $0.029^{* *}$ & $0.62^{* *}$ & 0.84 \\
& $(-0.46)$ & $(1.80)$ & $(3.99)$ & \\
\hline
\end{tabular}

Notes: - Empirical Model: $G M J_{t}=a_{5}+a_{6} G G D P_{t}+a_{7} G M J_{t-1}+e_{2 t}$.

- $G M J_{i}: G C C$ countries' imports from Japan in period $t$.

- GGDP: : GDP of GCC countries in period $t$.

- $e_{2 t}$ is a random iid error term.

- $t$-ratios are in parantheses.

- * and $* *$ denote statistical significane at the five and ten percent levels, respectively. 
- $J G D P_{t}:$ Japan's $G D P$ in period $t$.

- $G X J_{t}$ : Exports of $G C C$ countries to Japan in period $t$.

The exogenous variables in the model are defined as follows:

- GNOGDP: GCC Countries' non-oil GDP in period $t$.

- $J X N G_{t}:$ Japan's exports to countries other than $G C C$ in period $t$.

- GCCOIL $L_{t}: G C C$ countries' oil production value in period $t$.

All lagged variables, $G X J_{t-1}, G G D P_{t-1}, G M J_{t-1}, J G D P_{t-1}$.

All variables are measured in real values. ${ }^{13}$

The first equation of the model attempts to identify the relative significance of the oil and non-oil components of GDP in GCC countries. Hence, the model establishes the dependency of $G D P$ of the GCC countries on exports to Japan. Given that exports to Japan are dominated by oil, we account for other components of aggregate demand that are not related to oil production. Since other demand components are likely to be stimulated by oil exports, it is necessary to account for

Table 9. Exports to GCC Countries and GDP in Japan

\begin{tabular}{|lccccc|}
\hline Country & $a_{8}$ & $a_{9}$ & $a_{10}$ & $a_{11}$ & $R^{2}$ \\
\hline$G C C$ & -46330.87 & $-42.89^{*}$ & $7.83^{*}$ & $0.43^{*}$ & 0.90 \\
& $(-0.28)$ & $(-2.78)$ & $(4.28)$ & $(2.73)$ & \\
Bahrain & -19487.39 & $-1378.32^{* *}$ & $7.87^{*}$ & $0.40^{*}$ & 0.97 \\
& $(-0.084)$ & $(-1.77)$ & $(3.94)$ & $(2.30)$ & \\
Kuwait & 3022.97 & $-255.62^{*}$ & $8.46^{*}$ & 0.31 & 0.99 \\
& $(0.014)$ & $(-2.068)$ & $(4.14)$ & $(1.64)$ & \\
Oman & $-342415.3^{*}$ & $-832.6755^{*}$ & $2.088^{*}$ & $0.38^{*}$ & 0.95 \\
& $(-2.70)$ & $(-3.11)$ & $(4.65)$ & $(2.33)$ & \\
Qatar & -134626.9 & -515.05 & $5.71^{* *}$ & $0.60^{*}$ & 0.60 \\
& $(-0.26)$ & $(-0.46)$ & $(1.88)$ & $(2.59)$ & \\
Saudi Arabia & -61277.64 & $-61.26^{*}$ & $7.81^{*}$ & $0.41^{*}$ & 0.87 \\
& $(-0.40)$ & $(-2.91)$ & $(4.33)$ & $(2.66)$ & \\
UAE & -272761.5 & -88.88 & $6.67^{*}$ & $0.57^{*}$ & 0.98 \\
& $(-1.39)$ & $(-0.65)$ & $(3.12)$ & $(3.051)$ & \\
\hline
\end{tabular}

Notes: $\bullet$ Empirical Model: $J G D P_{t}=a_{8}+a_{9} G M J_{t}+a_{10} J X N G_{t}+a_{11} J G D P_{t}+e_{3 t}$.

- JGDP: Japan's $G D P$ in period $t$.

- $G M J_{t}$ : GCC countries' imports from Japan in period $t$.

- $J X N G_{t}$ : Japan's exports to countries other than $G C C$ in period $t$.

- $e_{3 t}$ is a random iid error term.

- $t$-ratios are in parantheses.

-* and ** denote statistical significance at the five and ten percent levels, respectively.

\footnotetext{
${ }^{13}$ In 1977, the Japan-ASEAN Committee was formed to promote and negotiate the issues related to trade relationship between Japan and the Association of South East Asian Nations (ASEAN). For more details, see the Four Tigers (1995).
} 
these components explicitly to avoid the omitted variable bias in the coefficient measuring the effect of exports to Japan on GDP. The second equation tests the relationship between the imports of the $G C C$ countries from Japan and their income. That is, to what extent does the increase in income of the GCC countries raise their demand for Japanese goods? The third equation seeks to identify the significance of exports to Japan's GDP and to distinguish between the relative importance of exports to $G C C$ as well as non-GCC countries. Finally, equation four establishes variation in the $G C C$ countries' exports to Japan with $G D P$ in Japan. In this equation, we introduce the $G C C$ oil production since oil dominates the $G C C$ countries exports to Japan. ${ }^{14}$ All lagged dependent variables are introduced into the right-hand side of the system to account for possible persistence in variables' adjustments and introduce dynamics into the model specification.

The system contains four equations and ten variables, four endogenous and

Table 10. Japan's GDP and GCC Countrie's Exports to Japan

\begin{tabular}{|lccccc|}
\hline Country & $a_{12}$ & $a_{13}$ & $a_{14}$ & $a_{15}$ & $R^{2}$ \\
\hline$G C C$ & $5932.43^{*}$ & 0.001 & $0.19^{*}$ & 0.088 & 0.86 \\
\multirow{4}{*}{ Bahrain } & $(2.13)$ & $(0.19)$ & $(5.91)$ & $(0.60)$ & \\
& 359.40 & $-0.00002^{* *}$ & $0.15^{*}$ & -0.25 & 0.41 \\
Kuwait & $(4.91)$ & $(01.88)$ & $(3.17)$ & $(-1.22)$ & \\
& -362.73 & -0.00002 & $0.17^{*}$ & $0.42^{*}$ & 0.71 \\
Oman & $(-0.46)$ & $(-0.14)$ & $(2.91)$ & $(2.12)$ & \\
& 246.8 & -0.00021 & 0.25 & $0.49^{*}$ & 0.46 \\
Qatar & $(0.49)$ & $(-1.34)$ & $(1.57)$ & $(2.51)$ & \\
& -247.28 & $0.00015^{*}$ & $0.21^{*}$ & $0.57^{*}$ & 0.79 \\
Saudi Arabia & $(-0.90)$ & $(2.073)$ & $(2.86)$ & $(4.36)$ & \\
& 2694.86 & -0.00017 & $0.11^{*}$ & 0.30 & 0.81 \\
UAE & $(1.20)$ & $(-0.35)$ & $(3.37)$ & $(1.49)$ & \\
& -806.20 & $0.00044^{*}$ & $0.31^{*}$ & $0.38^{*}$ & 0.82 \\
& $(0.91)$ & $(2.19)$ & $(4.89)$ & $(3.016)$ & \\
\hline
\end{tabular}

Notes: • Empirical Model: $G X J_{t}=a_{12}+a_{13} J G D P_{t}+a_{14} G C C O I L_{t}+a_{15} G X J_{t-1}+e_{4 t}$.

- $G X J_{t}$ : Exports of $G C C$ countries to Japan in period $t$.

- $J G D P_{t}:$ Japan's $G D P$ in period $t$.

- $G C C O I L_{t}: G C C$ countries' oil production value in period $t$.

- $e_{4 t}$ is a random iid error term.

- $t$-ratios are in parantheses.

-* and ${ }^{* *}$ denote statistical significance at the five and ten percent levels, respectively.

\footnotetext{
${ }^{14}$ Hence, the model seeks to identify the quantity effects in trade relations between Japan and GCC countries. The effects of prices are embeded in the measurement of realized exports and imports between Japan and GCC countries.
} 
seven exogenous. The first equation contains four variables. The second equation contains three variables and the last two equations contain four variables. Thus, the number of excluded variables from each equation is greater than the total number of equations minus one. Hence, every equation is over identified.

We estimate the system of equations using 2SLS over the sample period 19751995. ${ }^{15}$ To formalize the effects of trade interaction between Japan and individual $G C C$ countries, we estimate the empirical models in (1) through (4), replacing variables for $G C C$ countries with their equivalent for each country.

The results of estimating model (1) are summarized in Table 7. Upon reviewing these results, we note the following. Exports to Japan are essential in increasing $G D P$ of the GCC countries. This is evident, by the positive and statistically significant effect $a_{2}$ of exports to Japan on GDP in GCC countries, collectively and individually. ${ }^{16}$ Non-oil sources of domestic demand have positive effect $a_{3}$ on GDP in GCC countries, collectively and individually, except for Qatar and UAE due the small size of this sector. Nonetheless, the positive effect $a_{4}$ does not persist over time on GDP in GCC countries, except for Kuwait and Bahrain. This is consistent with the nature of exports to Japan, which are primarily in the form of crude oil. Accordingly, the positive effect of these exports is limited to the period of production.

The results of estimating model (2) are summarized in Table 8. Imports from Japan vary positively with $G D P$ with a coefficient $a_{6}$ that is statistically significant in $G C C$ countries and in Kuwait, Oman, Saudi Arabia, and UAE. In all these cases, the lagged dependent variable has a positive and statistically significant effect $a_{7}$ on the GCC countries' imports from Japan. This indicates that the increase in GDP has persistent positive effect on imports from Japan in the GCC countries. In two cases, however, Bahrain and Qatar, imports from Japan do not vary positively and significantly with $G D P$ indicating no systematic dependency, in contrast to theory's predictions. That is, as GDP grows in these countries, their imports from Japan do not grow and may be even declining. In the case of Bahrain, the relation between imports from Japan and GDP is negative and statistically significant. That is because the value of imports from Japan to Bahrain (see Table 6) grew over time despite Bahrain's low production of oil. Despite the evidence of the increased imports from Japan in Qatar over time (see Table 6), this

\footnotetext{
${ }^{15}$ While other exogenous factors may improve the goodness of fit, analyzing these factors is beyond the scope of this paper and is not likely to affect the relationship under investigation.

${ }^{16}$ The estimation procedure accounts for instrumental variables and corrects for serial correlation.
} 
increase does not vary significantly with the increase in GDP.

The results of estimating model (3) are summarized in Table 9. The results highlight the effects of exports to GCC countries and non- $G C C$ countries on GDP in Japan. Japan's GDP is not dependent on exports to GCC countries. This is evident by the negative response $a_{9}$ of $G D P$ to the increased exports to $G C C$ countries. That is, GDP growth in Japan may be increasing despite a decrease in exports to GCC countries. In contrast, exports to non- $G C C$ countries have a positive effect $a_{10}$ on $G D P$ in Japan witha coefficient that is statistically significant. ${ }^{17}$ That is, Japan's GDP is not dependent on exports to GCC countries, in contrast to its dependency on exports to non- $G C C$ countries. Further, the response of $G D P$ in Japan to its lag $a_{11}$ is positive and statistically significant in many $G C C$ countries. That is, exports have persistent effect on GDP in Japan over time. Since exports in Japan are predominantly manufactured, they are likely to result an increase in the productive base that carries its positive effect on $G D P$ over time.

The results of estimating model (4) test the dependency of GCC countries' exports to Japan on income in Japan and oil production. In general, exports from GCC countries to Japan do not vary positively and significantly $a_{13}$ with income in Japan. ${ }^{18}$ The only exceptions are in Qatar and UAE where Japan's imports increase with GDP in Japan, indicating an increase in the marginal propensity to import from Qatar and UAE with income in Japan. On the other hand, exports from GCC countries to Japan are highly dependent on supply-side conditions. This is evident by the positive and statistically significant effect $a_{14}$ of oil production on the GCC countries' exports to Japan. Where the lagged dependent variable is statistically significant, the positive effect $a_{15}$ of oil production persists on GCC countries' exports to Japan over time.

\section{Conclusions}

The main findings of this study are as follows:

- Economies of the GCC countries are dependent, to a large extent, on oil

\footnotetext{
${ }^{17}$ Where the coefficient in Table 7 is larger than one, a one Dinar in exports of GCC to Japan may cause an increase in GDP of GCC countries by more than one. That is because the marginal propensity to spend domestically allows for an additional spending that accumulates over time following an increase in exports.

${ }^{18} \mathrm{The} \mathrm{R}^{2}$ measure indicates the goodness of fit, as identified by the explanatory power of the model compared to the residual, capturing the effect of other endogenous and exogenous factors, other than exports, explaining Japan's GDP.
} 
exports. Subsequently, political events determining fluctuations in the oil price produce large economic results in $G C C$ countries.

- Japan is the main importer of the GCC countries' oil exports.

- Japan's exports occupies a big segment of the GCC markets.

- While Japan's oil imports from GCC countries have a large impact on their economies, the effect of GCC countries' imports from Japan is minor in the huge Japanese market.

- The trade relationship between Japan and GCC countries combined is stronger than trade relationships between Japan and individual countries of GCC. The trade relationship between Japan and GCC countries captures the combined effects of relationships with individual countries. Hence, weak effects are reinforced upon aggregating over $G C C$ countries. The implication is that GCC countries can maximize their benefits be establishing a united front in negotiations with major trading partners, including Japan.

Date accepted: March 2001

\section{References}

Al Ahram Center for Strategic and Political Studies, The Asian Tigers, Cairo 1995, 197 (in Arabic).

American Statistics Index, 1996.

International Energy Agency (1998), Oil Market Report, April 10.

International Monetary Fund (1997), International Financial Statistics.

Japan External Trade Organization Statistics, JETRO, 1975-1997.

Kandil, Magda and Mohammady Metwally (1990), The Impact of Migrants,

"Remittances on the Egyptian Economy, International Migration, 159-180.

Metwally, M. M. and Tamaschke, H. U., "Oil Exports and Economic Growth in the

Middle East," Kyklos, Geneva, 33(3), 499-522.

Metwally, M. M. (1988), “Trade Relationship between Saudi Arabia and Japan,” Journal of Administrative and Science, King Saud University, 13(1), 3-16.

OPEC Bulletin, March, 1998, 5-23.

The Secretariat General Cooperation Council for the Arab States of Gulf (1997),

Economic Bulletin, 12.

United Nations, Direction of Trade Statistics, Yearbook, 1975-1996.

World Alamank Books, The World Alamanac and Book of Facts, 1997, an imprint of K-

111, References Corporation, K.111 Communication Company.

\footnotetext{
${ }^{19}$ In these cases, it may be argued that the adverse effects of the oil price on the Japanese economy slow down growth in Japan and, hence, the countrys imports from GCC countries.
} 
Appendix 1. Trade Figures between Bahrain \& Japan

\begin{tabular}{|c|c|c|c|c|}
\hline & $B R \times J=$ & BRMJ $=$ & $\mathrm{B} 1=$ & $B 2=$ \\
\hline Year & $\begin{array}{c}\text { Bahrain Real Exports } \\
\text { to Japan } \\
\text { (Millions US dollar) }\end{array}$ & $\begin{array}{c}\text { Bahrain Real Imports } \\
\text { from Japan } \\
\text { (Millions US dollar) }\end{array}$ & $\begin{array}{l}\text { BRXJ/Bahrain } \\
\text { Total Real } \\
\text { Exports }\end{array}$ & $\begin{array}{c}\text { BRMJ/Bahrain } \\
\text { Total Real } \\
\text { Imports }\end{array}$ \\
\hline 1975 & 283.4404 & 115.4448 & 14.12537 & 5.776294 \\
\hline 1976 & 335.6291 & 197.0533 & 15.25524 & 8.160567 \\
\hline 1977 & 333.4029 & 229.0585 & 13.74844 & 8.579022 \\
\hline 1978 & 410.4745 & 208.5186 & 20.38996 & 8.239151 \\
\hline 1979 & 339.0223 & 189.9868 & 12.15940 & 6.832998 \\
\hline 1980 & 460.3124 & 277.9325 & 11.98338 & 7.497560 \\
\hline 1981 & 376.6711 & 263.3011 & 8.460229 & 6.234239 \\
\hline 1982 & 288.5905 & 279.2046 & 7.708751 & 7.819374 \\
\hline 1983 & 456.2219 & 414.6402 & 14.53705 & 12.65111 \\
\hline 1984 & 372.4210 & 350.9391 & 11.81980 & 9.921671 \\
\hline 1985 & 273.2933 & 217.5275 & 10.07940 & 7.326842 \\
\hline 1986 & 290.4937 & 249.9231 & 10.65933 & 9.947426 \\
\hline 1987 & 297.1518 & 279.8595 & 11.73439 & 9.719971 \\
\hline 1988 & 293.4036 & 277.6630 & 11.56328 & 9.749447 \\
\hline 1989 & 330.3171 & 300.5783 & 11.81885 & 9.320357 \\
\hline 1990 & 365.7000 & 255.5000 & 9.533368 & 6.884937 \\
\hline 1991 & 393.4535 & 175.1887 & 7.712024 & 2.921089 \\
\hline 1992 & 260.5234 & 220.2188 & 4.954440 & 3.502899 \\
\hline 1993 & 321.3056 & 235.4761 & 5.395248 & 4.190947 \\
\hline 1994 & 362.2037 & 162.8627 & 5.823667 & 2.982305 \\
\hline 1995 & 343.5039 & 107.5004 & 5.159817 & 2.050577 \\
\hline
\end{tabular}

\begin{tabular}{|c|c|c|c|}
\hline & $B J 1=$ & $\mathrm{BJ} 2=$ & $X M B J=$ \\
\hline Year & $\begin{array}{c}\text { BRXJ/Japan } \\
\text { Total Real } \\
\text { Imports }\end{array}$ & $\begin{array}{c}\text { BRMJ/Japan } \\
\text { Total Real } \\
\text { Exports }\end{array}$ & $\begin{array}{c}\text { Bahrain Current } \\
\text { Account } \\
\text { with Japan }\end{array}$ \\
\hline $\begin{array}{l}1975 \\
1976 \\
1977 \\
1978 \\
1979 \\
1980 \\
1981 \\
1982 \\
1983 \\
1984 \\
1985 \\
1986 \\
1987 \\
1988 \\
1989 \\
1990 \\
1991 \\
1992 \\
1993 \\
1994 \\
1995\end{array}$ & $\begin{array}{l}0.320476 \\
0.364623 \\
0.350508 \\
0.404707 \\
0.249719 \\
0.275621 \\
0.231488 \\
0.195980 \\
0.326551 \\
0.253247 \\
0.197082 \\
0.218178 \\
0.188483 \\
0.150411 \\
0.154287 \\
0.155426 \\
0.169612 \\
0.115933 \\
0.138840 \\
0.138210 \\
0.106956\end{array}$ & $\begin{array}{l}0.135479 \\
0.206362 \\
0.211874 \\
0.167064 \\
0.150245 \\
0.180265 \\
0.152592 \\
0.180171 \\
0.255332 \\
0.191497 \\
0.115539 \\
0.113603 \\
0.115919 \\
0.100708 \\
0.107166 \\
0.088819 \\
0.056756 \\
0.067129 \\
0.067802 \\
0.043106 \\
0.025382\end{array}$ & $\begin{array}{l}167.9956 \\
138.5758 \\
104.3445 \\
201.9560 \\
149.0355 \\
182.3799 \\
113.3700 \\
9.385860 \\
41.58170 \\
21.48197 \\
55.76577 \\
40.57057 \\
17.29230 \\
15.74053 \\
29.73883 \\
110.2000 \\
218.2648 \\
40.30455 \\
85.82948 \\
199.3410 \\
236.0035\end{array}$ \\
\hline
\end{tabular}


Appendix 2. Trade Figures between Kuwait \& Japan

\begin{tabular}{|c|c|c|c|c|}
\hline & $K X J=$ & $\mathrm{KMJ}=$ & $K 1=$ & $K 2=$ \\
\hline Years & $\begin{array}{c}\text { Kuwait Exports } \\
\text { to Japan } \\
\text { (Millions US dollar) }\end{array}$ & $\begin{array}{l}\text { Kuwait Imports } \\
\text { from Japan } \\
\text { (Millions US dollar) }\end{array}$ & $\begin{array}{c}\text { KXJ/Kuwait } \\
\text { Total } \\
\text { Exports }\end{array}$ & $\begin{array}{l}\text { KMJ/Kuwait } \\
\text { Total } \\
\text { Imports }\end{array}$ \\
\hline 1975 & 3681.889 & 645.6235 & 24.03092 & 16.20603 \\
\hline 1976 & 3174.909 & 999.7771 & 22.22222 & 20.72804 \\
\hline 1977 & 3232.839 & 1262.910 & 25.22042 & 19.84307 \\
\hline 1978 & 3214.455 & 1110.696 & 24.89690 & 19.48306 \\
\hline 1979 & 4960.019 & 1061.822 & 24.02840 & 18.25702 \\
\hline 1980 & 4352.006 & 1459.890 & 20.80049 & 21.00107 \\
\hline 1981 & 3955.149 & 1851.608 & 24.07130 & 25.68912 \\
\hline 1982 & 1525.449 & 1974.983 & 14.21208 & 24.12794 \\
\hline 1983 & 2054.568 & 1856.466 & 18.21106 & 25.67476 \\
\hline 1984 & 1445.516 & 1578.021 & 12.38923 & 22.77601 \\
\hline 1985 & 1091.738 & 1745.756 & 10.15543 & 26.65102 \\
\hline 1986 & 1115.429 & 1416.301 & 14.41149 & 23.01925 \\
\hline 1987 & 1749.387 & 1116.043 & 19.95402 & 18.75892 \\
\hline 1988 & 1516.653 & 873.0750 & 18.86568 & 13.28013 \\
\hline 1989 & 2178.961 & 833.5104 & 18.45155 & 12.66813 \\
\hline 1990 & 1557.100 & 460.0000 & 22.11162 & 11.18133 \\
\hline 1991 & 49.99898 & 462.4906 & 4.779412 & 9.442481 \\
\hline 1992 & 1021.518 & 791.0591 & 16.32583 & 13.56970 \\
\hline 1993 & 1421.551 & 990.5536 & 14.99805 & 17.49428 \\
\hline 1994 & 1929.020 & 626.6713 & 18.03145 & 10.18261 \\
\hline 1995 & 2548.230 & 574.3489 & 21.39261 & 8.010021 \\
\hline
\end{tabular}

\begin{tabular}{||cccc||}
\hline & KJ1= & KJ2= & XMKJ= \\
\hline Years & $\begin{array}{c}\text { KXJ/Japan } \\
\text { Total } \\
\text { Imports }\end{array}$ & $\begin{array}{c}\text { KMJ/Japan } \\
\text { Total } \\
\text { Exports }\end{array}$ & $\begin{array}{c}\text { Kuwait Current } \\
\text { Account } \\
\text { with Japan }\end{array}$ \\
\hline \hline 1975 & 4.162988 & 0.757663 & 3036.265 \\
1976 & 3.449180 & 1.047004 & 2175.132 \\
1977 & 3.398695 & 1.168164 & 1969.929 \\
1978 & 3.169289 & 0.889885 & 2103.759 \\
1979 & 3.653482 & 0.839709 & 3898.197 \\
1980 & 2.605844 & 0.946876 & 2892.115 \\
1981 & 2.430684 & 1.073070 & 2103.541 \\
1982 & 1.035921 & 1.274459 & -449.5333 \\
1983 & 1.470601 & 1.143199 & 198.1015 \\
1984 & 0.982954 & 0.861077 & -132.5056 \\
1985 & 0.787295 & 0.927252 & -654.0177 \\
1986 & 0.837754 & 0.643782 & -300.8722 \\
1987 & 1.109633 & 0.462272 & 633.3439 \\
1988 & 0.777501 & 0.316665 & 643.5780 \\
1989 & 1.017764 & 0.297173 & 1345.450 \\
1990 & 0.661782 & 0.159909 & 1097.100 \\
1991 & 0.021554 & 0.149833 & -412.4916 \\
1992 & 0.454576 & 0.241137 & 230.4594 \\
1993 & 0.614269 & 0.285214 & 430.9972 \\
1994 & 0.736076 & 0.165864 & 1302.349 \\
1995 & 0.793439 & 0.135613 & 1973.881 \\
\hline
\end{tabular}


Appendix 3. Trade Figures between Japan \& Oman

\begin{tabular}{|ccccc||}
\hline obs & OXJ= & OMJ= & O1= & O2= \\
\hline \hline & $\begin{array}{c}\text { Oman Exports } \\
\text { to Japan } \\
\text { (Millions US dollar) }\end{array}$ & $\begin{array}{c}\text { Oman Imports } \\
\text { from Japan } \\
\text { (Millions US dollar) }\end{array}$ & $\begin{array}{c}\text { OXJ/Oman } \\
\text { Total } \\
\text { Exports }\end{array}$ & $\begin{array}{c}\text { OMJ/Oman } \\
\text { Total } \\
\text { Imports }\end{array}$ \\
\hline \hline 1975 & 902.0378 & 88.25189 & 51.79119 & 7.897880 \\
1976 & 988.0235 & 127.5478 & 60.04409 & 13.17249 \\
1977 & 1060.660 & 156.2539 & 70.79825 & 13.59479 \\
1978 & 1062.033 & 181.8966 & 78.25730 & 15.50723 \\
1979 & 1536.789 & 214.9379 & 87.48408 & 15.41734 \\
1980 & 1764.531 & 362.4189 & 69.50126 & 19.66513 \\
1981 & 2367.355 & 528.6505 & 72.16984 & 22.55922 \\
1982 & 1569.415 & 548.0354 & 44.68354 & 20.67847 \\
1983 & 1794.584 & 537.8162 & 43.34202 & 22.00377 \\
1984 & 2202.504 & 587.4415 & 55.88640 & 21.29394 \\
1985 & 2881.471 & 651.6599 & 59.74283 & 12.23412 \\
1986 & 1557.826 & 359.3693 & 64.02413 & 11.58246 \\
1987 & 129.4271 & 294.2874 & 3.814884 & 16.80600 \\
1988 & 38.82665 & 388.1616 & 1.409524 & 15.70226 \\
1989 & 47.33516 & 364.6865 & 1.130777 & 16.98459 \\
1990 & 96.00000 & 463.0000 & 1.742919 & 20.47589 \\
1991 & 1890.346 & 628.8333 & 40.36132 & 23.26612 \\
1992 & 1679.826 & 823.8476 & 32.95715 & 20.89738 \\
1993 & 1309.640 & 795.1251 & 26.72813 & 17.89038 \\
1994 & 1711.348 & 645.1868 & 33.50488 & 16.11265 \\
1995 & 1716.783 & 630.4481 & 32.63173 & \\
\hline
\end{tabular}

\begin{tabular}{||cccc||}
\hline obs & OJ1= & OJ2= & XMOJ= \\
\hline & $\begin{array}{c}\text { OXJ/Japan } \\
\text { Total } \\
\text { Imports }\end{array}$ & $\begin{array}{c}\text { OMJ/Japan } \\
\text { Total } \\
\text { Exports }\end{array}$ & $\begin{array}{c}\text { Oman Current } \\
\text { Account with } \\
\text { Japan }\end{array}$ \\
\hline 1975 & 1.019904 & 0.103567 & 813.7859 \\
1976 & 1.073376 & 0.133573 & 860.4758 \\
1977 & 1.115076 & 0.144531 & 904.4064 \\
1978 & 1.047111 & 0.145735 & 880.1367 \\
1979 & 1.131978 & 0.169977 & 1321.851 \\
1980 & 1.056546 & 0.235063 & 1402.112 \\
1981 & 1.454886 & 0.306371 & 1838.704 \\
1982 & 1.065778 & 0.353648 & 1021.379 \\
1983 & 1.284512 & 0.331183 & 1256.768 \\
1984 & 1.497708 & 0.320549 & 1615.063 \\
1985 & 2.077941 & 0.346127 & 2229.811 \\
1986 & 1.170021 & 0.163352 & 1198.457 \\
1987 & 0.082095 & 0.121896 & -164.8604 \\
1988 & 0.019904 & 0.140786 & -349.3349 \\
1989 & 0.022110 & 0.130022 & -317.3514 \\
1990 & 0.040801 & 0.160952 & -367.0000 \\
1991 & 0.814901 & 0.203722 & 1261.513 \\
1992 & 0.747523 & 0.251132 & 855.9786 \\
1993 & 0.565911 & 0.228944 & 514.5145 \\
1994 & 0.653017 & 0.170765 & 1066.161 \\
1995 & 0.534553 & 0.148858 & 1086.335 \\
\hline
\end{tabular}


Appendix 4. Trade Figures between Qatar \& Japan

\begin{tabular}{||ccccc||}
\hline & QRXJ= & QRMJ= & Q1= & Q2 \\
\hline Year & $\begin{array}{c}\text { Qatar real Exports } \\
\text { to Japan } \\
\text { (Millions US dollar) }\end{array}$ & $\begin{array}{c}\text { Qatar real Imports } \\
\text { from Japan } \\
\text { (Millions US dollar) }\end{array}$ & $\begin{array}{c}\text { QRXJ/Qatar } \\
\text { Total } \\
\text { Exports }\end{array}$ & $\begin{array}{c}\text { QRTM/Qatar } \\
\text { Total } \\
\text { Imports }\end{array}$ \\
\hline \hline 1975 & 41.87377 & 102.7659 & 1.382387 & 15.04641 \\
1976 & 26.11900 & 341.8686 & 0.814701 & 28.28331 \\
1977 & 237.6005 & 429.4682 & 7.779355 & 26.67537 \\
1978 & 684.9910 & 289.4991 & 23.86540 & 19.74829 \\
1979 & 983.6123 & 296.1690 & 25.80882 & 18.57283 \\
1980 & 1556.401 & 280.8055 & 32.75997 & 18.32893 \\
1981 & 1837.475 & 317.8867 & 33.29313 & 20.45065 \\
1982 & 1599.449 & 423.0553 & 35.37497 & 21.99168 \\
1983 & 1517.732 & 311.5686 & 42.66652 & 21.82455 \\
1984 & 2362.515 & 223.9545 & 50.99896 & 18.20131 \\
1985 & 2054.928 & 211.8894 & 60.50161 & 16.95486 \\
1986 & 1089.744 & 195.3048 & 48.64751 & 16.26824 \\
1987 & 857.1890 & 196.3684 & 38.44507 & 17.60852 \\
1988 & 1087.041 & 234.1142 & 49.40857 & 17.46606 \\
1989 & 1437.754 & 238.3222 & 54.42717 & 14.64983 \\
1990 & 1960.000 & 248.3000 & 60.56860 & 13.61549 \\
1991 & 1886.981 & 225.1877 & 64.82674 & 15.94736 \\
1992 & 1865.847 & 301.9553 & 58.91602 & 13.45548 \\
1993 & 1791.598 & 235.2912 & 51.91906 & 11.40420 \\
1994 & 1810.097 & 202.4729 & 61.87028 & 13.67729 \\
1995 & 2000.779 & 249.0841 & 67.14065 & \\
\hline
\end{tabular}

\begin{tabular}{|cccc||}
\hline & QJ1= & QJ2= & XMQJ $=$ \\
\hline Year & $\begin{array}{c}\text { QRXJ/Japan } \\
\text { Total } \\
\text { Imports }\end{array}$ & $\begin{array}{c}\text { QRTM/Japan } \\
\text { Total } \\
\text { Exports }\end{array}$ & $\begin{array}{c}\text { Qatar Current } \\
\text { Account } \\
\text { with Japan }\end{array}$ \\
\hline \hline 1975 & 0.047345 & 0.120600 & -60.89214 \\
1976 & 0.028375 & 0.358017 & -315.7496 \\
1977 & 0.249790 & 0.397249 & -191.8677 \\
1978 & 0.675366 & 0.231945 & 395.4919 \\
1979 & 0.724515 & 0.234216 & 687.4433 \\
1980 & 0.931924 & 0.182129 & 1275.595 \\
1981 & 1.129242 & 0.184226 & 1519.588 \\
1982 & 1.086174 & 0.272998 & 1176.394 \\
1983 & 1.086349 & 0.191862 & 1206.164 \\
1984 & 1.606515 & 0.122205 & 2138.560 \\
1985 & 1.481889 & 0.112544 & 1843.038 \\
1986 & 0.818464 & 0.088776 & 894.4395 \\
1987 & 0.543714 & 0.081337 & 660.8206 \\
1988 & 0.557264 & 0.084913 & 852.9271 \\
1989 & 0.671556 & 0.084969 & 1199.432 \\
1990 & 0.833018 & 0.086316 & 1711.700 \\
1991 & 0.813450 & 0.072954 & 1661.793 \\
1992 & 0.830302 & 0.092044 & 1563.892 \\
1993 & 0.774171 & 0.067748 & 1556.307 \\
1994 & 0.690698 & 0.053590 & 1607.624 \\
1995 & 0.622980 & 0.058813 & 1751.695 \\
\hline
\end{tabular}


Appendix 5. Trade Figures between Saudi Arabia \& Japan

\begin{tabular}{|ccccc||}
\hline & SXJ= & SMJ= & S1= & S2= \\
\hline \hline Year & $\begin{array}{c}\text { Saudi Exports } \\
\text { to Japan } \\
\text { (Millions US dollar) }\end{array}$ & $\begin{array}{c}\text { Saudi Imports } \\
\text { to Japan } \\
\text { (Millions US dollar) }\end{array}$ & $\begin{array}{c}\text { SXJ/Saudi } \\
\text { Total } \\
\text { Exports }\end{array}$ & $\begin{array}{c}\text { SMJ/Saudi } \\
\text { Total } \\
\text { Imports }\end{array}$ \\
\hline 1975 & 9764.430 & 1076.039 & 19.71902 & 15.30976 \\
1976 & 11318.23 & 1533.765 & 20.37298 & 12.15781 \\
1977 & 10990.34 & 2232.761 & 19.24165 & 11.59410 \\
1978 & 9468.775 & 3884.340 & 18.80533 & 15.41599 \\
1979 & 11403.68 & 4299.877 & 16.06785 & 15.84285 \\
1980 & 18945.59 & 5757.629 & 16.32243 & 17.93741 \\
1981 & 19904.79 & 6611.715 & 16.21342 & 18.30555 \\
1982 & 17809.42 & 7684.549 & 22.79550 & 19.13266 \\
1983 & 13848.47 & 7479.803 & 30.79087 & 19.46607 \\
1984 & 12012.84 & 6713.617 & 31.87375 & 19.84805 \\
1985 & 8439.698 & 4590.425 & 29.95888 & 18.95690 \\
1986 & 4306.561 & 3151.295 & 20.35175 & 15.72834 \\
1987 & 5440.180 & 3681.245 & 22.10440 & 17.25510 \\
1988 & 4308.709 & 3654.952 & 16.84375 & 15.98880 \\
1989 & 5098.820 & 3101.482 & 17.45825 & 14.24857 \\
1990 & 8427.000 & 3689.000 & 18.97247 & 15.31913 \\
1991 & 6707.556 & 3829.730 & 14.59506 & 13.73448 \\
1992 & 8755.202 & 4412.832 & 18.53421 & 14.11655 \\
1993 & 7504.530 & 4178.638 & 19.13905 & 12.67179 \\
1994 & 8949.802 & 2990.575 & 22.79931 & 9.055872 \\
1995 & 9854.205 & 2489.367 & 21.37790 & 7.183510 \\
\hline
\end{tabular}

\begin{tabular}{|cccc|}
\hline & SJ1= & SJ2= & XMSJ= \\
\hline Year & $\begin{array}{c}\text { SXJ/Japan } \\
\text { Total } \\
\text { Imports }\end{array}$ & $\begin{array}{c}\text { EMJ/Japan } \\
\text { Total } \\
\text { Exports }\end{array}$ & $\begin{array}{c}\text { Saudi Current } \\
\text { Account } \\
\text { with Japan }\end{array}$ \\
\hline 1975 & 11.04031 & 1.262771 & 8688.390 \\
1976 & 12.29598 & 1.606216 & 9784.466 \\
1977 & 11.55418 & 2.065255 & 8757.576 \\
1978 & 9.335729 & 3.112116 & 5584.435 \\
1979 & 8.399794 & 3.400425 & 7103.804 \\
1980 & 11.34402 & 3.734364 & 13187.96 \\
1981 & 12.23272 & 3.831715 & 13293.07 \\
1982 & 12.09425 & 4.958849 & 10124.87 \\
1983 & 9.912342 & 4.606010 & 6368.670 \\
1984 & 8.168758 & 3.663412 & 5299.220 \\
1985 & 6.086197 & 2.438187 & 3849.273 \\
1986 & 3.234487 & 1.432427 & 1155.265 \\
1987 & 3.450698 & 1.524793 & 1758.935 \\
1988 & 2.208828 & 1.325652 & 653.7569 \\
1989 & 2.381592 & 1.105776 & 1997.338 \\
1990 & 3.581553 & 1.282399 & 4738.000 \\
1991 & 2.891530 & 1.240713 & 2877.826 \\
1992 & 3.896064 & 1.345154 & 4342.370 \\
1993 & 3.242798 & 1.203172 & 3325.892 \\
1994 & 3.415070 & 0.791532 & 5959.226 \\
1995 & 3.068292 & 0.587778 & 7364.838 \\
\hline
\end{tabular}


Appendix 6. Trade Figures between Emirates \& Japan

\begin{tabular}{|ccccc||}
\hline obs & EXJ= & ERMJ= & E1= & E2= \\
\hline \hline & $\begin{array}{c}\text { Emirates } \\
\text { Exports to Japan } \\
\text { (Millions US dollar) }\end{array}$ & $\begin{array}{c}\text { Emirates } \\
\text { Imports from Japan } \\
\text { (Millions US dollar) }\end{array}$ & $\begin{array}{c}\text { EXJ/Emirates } \\
\text { Total } \\
\text { Exports }\end{array}$ & $\begin{array}{c}\text { EMJ/Emirates } \\
\text { Total } \\
\text { Imports }\end{array}$ \\
\hline \hline 1975 & 2690.932 & 730.7056 & 22.21151 & 15.90414 \\
1976 & 3395.469 & 864.8289 & 24.54116 & 17.42690 \\
1977 & 3252.551 & 1285.251 & 25.68493 & 18.85847 \\
1978 & 2838.032 & 1220.899 & 25.11506 & 18.31012 \\
1979 & 3809.805 & 1309.096 & 24.94140 & 16.78382 \\
1980 & 7959.170 & 1598.218 & 36.17721 & 16.97559 \\
1981 & 8203.197 & 1677.508 & 37.71542 & 16.97233 \\
1982 & 5787.618 & 1733.914 & 34.79242 & 17.24477 \\
1983 & 6953.167 & 1589.716 & 48.32334 & 19.39923 \\
1984 & 7030.827 & 1257.799 & 49.35175 & 17.79071 \\
1985 & 8371.016 & 1323.412 & 58.14997 & 17.61015 \\
1986 & 5738.586 & 1202.440 & 44.19149 & 16.41385 \\
1987 & 5255.587 & 1316.549 & 34.97353 & 16.72080 \\
1988 & 5085.242 & 1469.117 & 34.77824 & 15.04341 \\
1989 & 5633.913 & 1479.738 & 31.11503 & 14.21722 \\
1990 & 8257.000 & 1631.000 & 35.07051 & 17.24664 \\
1991 & 9189.236 & 2282.646 & 39.11033 & 17.25049 \\
1992 & 8313.636 & 2822.258 & 35.30943 & 14.35963 \\
1993 & 7566.498 & 2592.457 & 30.52726 & 10.36302 \\
1994 & 7655.836 & 2279.893 & 30.34873 & 8.740467 \\
1995 & 8517.129 & 2132.506 & 32.93439 & \\
\hline
\end{tabular}

\begin{tabular}{|cccc||}
\hline obs & EJ1= & EJ2= & XMEJ= \\
\hline \hline & $\begin{array}{c}\text { EXJ/Japan } \\
\text { Total } \\
\text { Imports }\end{array}$ & $\begin{array}{c}\text { EMJ/Japan } \\
\text { Total } \\
\text { Exports }\end{array}$ & $\begin{array}{c}\text { Emirates Current } \\
\text { Account } \\
\text { with Japan }\end{array}$ \\
\hline \hline 1975 & 3.042546 & 0.857510 & 1960.226 \\
1976 & 3.688794 & 0.905681 & 2530.640 \\
1977 & 3.419419 & 1.188829 & 1967.301 \\
1978 & 2.798155 & 0.978179 & 1617.134 \\
1979 & 2.806250 & 1.035258 & 2500.709 \\
1980 & 4.765700 & 1.036595 & 6360.951 \\
1981 & 5.041372 & 0.972173 & 6525.689 \\
1982 & 3.930328 & 1.118897 & 4053.704 \\
1983 & 4.976879 & 0.978936 & 5363.451 \\
1984 & 4.780979 & 0.686342 & 5773.028 \\
1985 & 6.036667 & 0.702925 & 7047.604 \\
1986 & 4.310025 & 0.546572 & 4536.146 \\
1987 & 3.333611 & 0.545322 & 3939.038 \\
1988 & 2.606912 & 0.532849 & 3616.125 \\
1989 & 2.631527 & 0.527573 & 4154.175 \\
1990 & 3.509301 & 0.566981 & 6626.000 \\
1991 & 3.961346 & 0.739506 & 6906.590 \\
1992 & 3.699568 & 0.860303 & 5491.378 \\
1993 & 3.269575 & 0.746457 & 4974.040 \\
1994 & 2.921318 & 0.603432 & 5375.942 \\
1995 & 2.651968 & 0.503517 & 6384.622 \\
\hline
\end{tabular}

